\title{
The Relationship Between Adma and Anthropometric, Glucose, Lipid, and Inflammatory Parameters in Obese
}

\author{
Dharma Lindarto ${ }^{1^{*}}$, Brama Ihsan Sazli ${ }^{2}$ \\ ${ }^{1,2}$ Department of Internal Medicine, Faculty of Medicine, Universitas Sumatera Utara
}

\begin{abstract}
Asymmetric dimethylarginine (ADMA) is an endogenous inhibitor of nitric oxide production and involved in various pathological processes, especially processes involving cardiovascular risk. The purpose of this study was to analyze the correlation between ADMA and anthropometric, glucose, lipid, and inflammatory parameters. The study was analyzed by a cross-sectional study of 45 obese subjects at H. Adam Malik Hospital. Blood tests were carried out after 8-10 hours of fasting against cardiovascular risk: anthropometry (body weight, BMI, and WC), glucose (FPS, PPS, HbA1C, Fasting Insulin, and HOMA-IR), lipid (LDL-C, HDL-C, TG, and sd-LDL), and inflammation (ApoB and hs-CRP) parameters. The results showed of the 45 subjects, the average age was $41.69 \pm 5.69$ years old, and the average BMI was $33.09 \pm 5.05$ (Obesity I). ADMA was also found to be correlated significantly with FPG, HBA1c, and TG parameters $[\mathrm{r}=-0.506$, $\mathrm{p}=0.001 ; \mathrm{r}=-0.334, \mathrm{p}=0.013$, dan $\mathrm{r}=-0.315$. $\mathrm{p}=0.017$, respectively]. In obesity, ADMA correlated significantly with cardiovascular risk parameters: FPG, HbA1C, and TG.
\end{abstract}

Keyword: ADMA, Obesity, Cardiovascular risk factor

\begin{abstract}
Abstrak. Asymmetric dimethylarginine (ADMA) adalah penghambat endogen dari produksi oksida nitrat dan terlibat dalam berbagai proses patologis, terutama proses yang melibatkan risiko kardiovaskular. Tujuan dari penelitian ini adalah untuk menganalisis korelasi antara ADMA dan parameter antropometrik, glukosa, lipid, dan inflamasi. Penelitian ini dianalisis dengan studi cross-sectional pada 45 subyek obesitas di Rumah Sakit H. Adam Malik. Tes darah dilakukan setelah 8-10 jam puasa terhadap risiko kardiovaskular: antropometri (berat badan, BMI, dan WC), glukosa (FPS, PPS, HbAlC, Insulin Puasa, dan HOMA-IR), lipid (LDL-C, Parameter HDL-C, TG, dan sd-LDL), dan peradangan ( $A$ poB dan hs-CRP). Hasil penelitian menunjukkan dari 45 subjek, usia ratarata adalah 41,69 \pm 5,69 tahun, dan rata-rata BMI adalah 33,09 \pm 5,05 (Obesitas I). ADMA juga ditemukan berkorelasi secara signifikan dengan parameter $F P G$, HBAlc, dan $T G[r=-0.506, p=0,001 ; r=-0,334, p=0,013$, dan $r=-0,315 . p=0,017$, masingmasing]. Pada obesitas, ADMA berkorelasi signifikan dengan parameter risiko kardiovaskular: FPG, HbAlC, dan TG.
\end{abstract}

Kata Kunci: ADMA, Obesitas, faktor risiko kardiovaskular

Received [date month year] | Revised [date month year] | Accepted [xx Month xxxx]

\footnotetext{
*Corresponding author at: Faculty of Medicine, Universitas Sumatera Utara, H. Adam Malik Hospital, Jalan Bunga Lau No 17, Medan 20136, Indonesia

E-mail address: dharma@usu.ac.id
} 


\section{Introduction}

Asymmetrical dimethylarginine (ADMA) is an endogenous inhibitor of nitric oxide synthase (NO) which appears as a risk marker for various disease conditions including end-stage kidney failure [1], liver failure [2], heart failure [3], diabetes [4], pre-eclampsia [5], and atherosclerotic [6]. It has been observed that ADMA is positively correlated with NO serum concentration and body mass index (BMI) [7].

Inflammation measured by $\mathrm{C}$-reactive protein (CRP) is another strong risk marker for predicting cardiovascular death and complications including inflammatory diseases [8], sepsis [9], lung disease [10], and coronary heart disease [11]. The interaction between ADMA and CRP is a problem of cardiovascular disease because both ADMA and CRP factors are involved in endothelial dysfunction in humans [12].

Obesity increases the risk of morbidity due to hypertension, dyslipidemia, T2DM, coronary heart disease (CHD), stroke, gallbladder disease, osteoarthritis, sleep apnea, respiratory disorders, and certain types of cancer. Obesity is also associated with an increased risk of all causes of death due to cardiovascular disease (CVD) [13]. Obesity is caused by abnormal or excessive fat accumulation due to metabolic disorders [14]. According to previous research, the main determinant of obesity is insulin resistance which is associated with endothelial dysfunction [15]. Obesity can trigger the activity of tumor necrosis factor in $\alpha$ pro-inflammatory cytokine, which then inhibits the insulin receptor substrate 1 in the insulin signaling pathway [16].

Based on several studies, ADMA has a positive correlation with cardiovascular risk factors in prediabetes [17], angina pectoris [7], IGT, and obesity [18]. Therefore, the aim of this study was to investigate the correlation between ADMA and anthropometric, glucose, lipid, and inflammatory parameters in obesity.

\section{Method}

The study design was a cross-sectional study by recruiting 45 nurses at $\mathrm{H}$. Adam Malik Hospital aged 30-55 years who met the criteria for obesity [19] and signed an informed consent form. Subjects were excluded from the study if they had secondary illness or obesity that could affect markers of metabolic disorders, lipid profiles, and inflammations such as pregnancy or lactation, acute infection, anemia, menopause, diabetes or hypertension, cardiovascular disease, chronic kidney disease or liver dysfunction, smoked, consumed corticosteroids, estrogen, betaadrenergic receptor agonists, nitrates, or other vasodilator agents [20]. Venous blood samples were collected from the subjects in the morning after 10-12 hours of fasting combined with ethylenediaminetetraacetate (EDTA) containing heparin, then centrifuged. 


\subsection{Biochemical Analysis}

Serum glucose levels, HDL cholesterol (HDL-C), and triglycerides (TG) were measured by the enzymatic colorimetric method while Apo-B and hs-CRP levels were measured by the immunoassay method with Hitachi Modular analyzer using the Roche Diagnostic kit. Insulin levels were measured by the chemiluminescence immunoassay method using the DPC Immulite-I analyzer (Diagnostic Products Corp, Los Angeles, CA, USA) kit.

The HbA1c values were measured using the High-Performance Liquid Chromatography (HPLC) method which was in accordance with the American Diabetes Association standard [21]. ADMA levels were examined using ELISA method with a normal range of 0.4-0.75 $\mu \mathrm{mol} / \mathrm{L}(80-150 \mathrm{ng} / \mathrm{mL})$ [22]. The HOMA-IR formula $=[($ fasting glucose serum $(\mathrm{mmol} / \mathrm{l}) \mathrm{x}$ fasting insulin $(\mu \mathrm{U} / \mathrm{ml}) / 22,5]$ was used to determine the index of insulin resistance [23].

\subsection{Statistical Analysis}

The mean and standard deviation were summarized as descriptive statistics. The Shapiro-Wilk test was used to determine whether a variable was normally distributed. The parametric test was performed on variables with normal distribution, whereas the nonparametric test was performed on variables with abnormal distribution. Furthermore, the Pearson and Spearman test was used to evaluate the correlation between variables according to the variable distribution. $\mathrm{P}<0.05$ was accepted as an indication of statistical significance. SPSS for Windows 22.0 was used for the statistical analysis.

\section{Results}

From the 45 obese patients who met the inclusion criteria, the average age was $41.69 \pm 5.69$ years, and the average BMI was $33.09 \pm 5.05$ (Obesity I).

Table 1. shows the characteristics of the research subjects in terms of anthropometric, glucose, lipid, inflammatory parameters in obesity, while Table 2. shows the correlation analysis between ADMA and the subject parameters. There was a significant correlation between the levels of ADMA and fasting blood glucose (FBG), HbA1c, and TG. 
Table 1 Baseline Characteristic of Obesity Subjects

\begin{tabular}{|c|c|c|}
\hline Para & $\begin{array}{l}\text { neters } \\
\text { (years) }\end{array}$ & $\begin{array}{c}\text { Total }(\text { mean } \pm \text { SD }) ; \mathbf{n}=\mathbf{4 5} \\
41.69 \pm 5.69\end{array}$ \\
\hline Body weight & $(\mathrm{Kg})$ & $78.79 \pm 13.26$ \\
\hline BMI & $\left(\mathrm{kg} / \mathrm{m}^{2}\right)$ & $33.09 \pm 5.05$ \\
\hline WC & $(\mathrm{cm})$ & $96.34 \pm 9.33$ \\
\hline ADMA & (umol/l) & $0.82 \pm 0.13$ \\
\hline FPG & $(\mathrm{mg} / \mathrm{dl})$ & $86.00 \pm 10.94$ \\
\hline PPG & $(\mathrm{mg} / \mathrm{dl})$ & $109.84 \pm 28.56$ \\
\hline HbA1C & $(\%)$ & $5.56 \pm 0.56$ \\
\hline Fasting Insulin & $(\mu \mathrm{IU} / \mathrm{mL})$ & $9.52 \pm 7.32$ \\
\hline HOMA-IR & & $1.24 \pm 0.91$ \\
\hline LDL-C & $(\mathrm{mg} / \mathrm{dl})$ & $137.51 \pm 33.51$ \\
\hline HDL-C & $(\mathrm{mg} / \mathrm{dl})$ & $47.06 \pm 12.84$ \\
\hline TG & $(\mathrm{mg} / \mathrm{dl})$ & $151.22 \pm 57.31$ \\
\hline sd-LDL & $(\mathrm{mg} / \mathrm{dl})$ & $1.34 \pm 0.26$ \\
\hline ApoB & $(g / L)$ & $104.31 \pm 18.41$ \\
\hline hs-CRP & $(\mathrm{mg} / \mathrm{L})$ & $3.64 \pm 2.38$ \\
\hline \multicolumn{3}{|c|}{$\begin{array}{l}\text { Abbreviations: BMI, body mass index; WC, waist circumference; ADMA, asymmetric dimethylarginine; } \\
\text { FPG, fasting plasma glucose; PPG, postprandial plasma glucose; HbA1c, glycosylated hemoglobin; } \\
\text { HOMA-IR: homeostasis model assessment of insulin resistance;; LDL-C, low density lipoprotein } \\
\text { cholesterol; HDL-C, high density lipoprotein cholesterol; TG, triglycerides; ApoB: apolipoprotein B; sd- } \\
\text { LDL: small dense-LDL; CRP, C-reactive protein; }\end{array}$} \\
\hline
\end{tabular}

In Table 2, After 12 weeks of lifestyle modification, there was decrease significantly on BW, BMI, WC, SBP, and chemerin in both groups. There was no decrease significantly of chemerin on both groups.

Table 2 Relationship Between ADMA and Anthropometry, Glucose, Lipid, and Inflammation Parameters

\begin{tabular}{llcc}
\hline \multicolumn{2}{c}{ Parameter } & r & P \\
\hline Age & $(\mathrm{year})$ & -0.057 & 0.356 \\
Body weight & $(\mathrm{Kg})$ & -0.056 & 0.407 \\
BMI & $\left(\mathrm{kg} / \mathrm{m}^{2}\right)$ & -0.117 & 0.445 \\
WC & $(\mathrm{cm})$ & -0.100 & 0.256 \\
FPS & $(\mathrm{mg} / \mathrm{dl})$ & -0.506 & $0.001^{*}$ \\
PPS & $(\mathrm{mg} / \mathrm{dl})$ & -0.230 & 0.064 \\
HbA1C & $(\%)$ & -0.334 & $0.013^{*}$ \\
Fasting Insulin & $(\mu \mathrm{IU} / \mathrm{mL})$ & -0.102 & 0.255 \\
HOMA-IR & & -0.225 & 0.069 \\
LDL-C & $(\mathrm{mg} / \mathrm{dl})$ & -0.149 & 0.165 \\
HDL-C & $(\mathrm{mg} / \mathrm{dl})$ & 0.154 & 0.157 \\
TG & $(\mathrm{mg} / \mathrm{dl})$ & -0.315 & $0.017^{*}$ \\
sd-LDL & $(\mathrm{mg} / \mathrm{dl})$ & -0.042 & 0.392 \\
ApoB & $(\mathrm{g} / \mathrm{L})$ & -0.168 & 0.135 \\
hs-CRP & $(\mathrm{mg} / \mathrm{L})$ & -0.059 & 0.351 \\
\hline
\end{tabular}

Abbreviations: BMI, body mass index; WC, waist circumference; FPG, fasting plasma glucose; PPG, postprandial plasma glucose; HbA1c, glycosylated hemoglobin; HOMA-IR: homeostasis model assessment of insulin resistance; LDL-C, low density lipoprotein cholesterol; HDL-C, high density lipoprotein cholesterol; TG, triglycerides; ApoB: apolipoprotein B; sd-LDL: small dense-LDL; $\mathrm{CRP}, \mathrm{C}$-reactive protein; $* \mathrm{p}<0.05$.

\section{Discussion}

ADMA is believed to be a mediator that affects the risk of atherosclerosis. Several clinical studies have shown that increased ADMA is present in the conditions of chronic kidney 
insufficiency, dyslipidemia, hypertension, diabetes mellitus, and hyperhomocysteinemia, and other conditions [24]. The presence of cardiovascular disease risk factors, especially atherosclerotic disease will induce functional and morphological changes in endothelium, become easily inflamed, thrombosis, and vasoconstriction [25]. The dysfunctional endothelium can be detected by an imbalance between widening and constricting factors, procoagulant factors, and anticoagulant factors which stimulate and inhibit the development and proliferation of cells [26].

Other clinical evidence also supported that increased plasma ADMA was associated with decreased NO synthesis [27]. Plasma ADMA levels can change rapidly in response to changes in the risk factors. In diabetic patients, a few hours after high-fat eating, plasma ADMA level increases, and vasodilation is reduced [28]. In low body mass index (BMI) condition, each 0.1 $\mu \mathrm{mol} / \mathrm{L}$ increase in the plasma ADMA level was associated with an increased risk of acute myocard infarct (AMI) with HR (95\% CI) 1.21 (1.08-1.35) and cardiovascular death 1.30 (1.13-

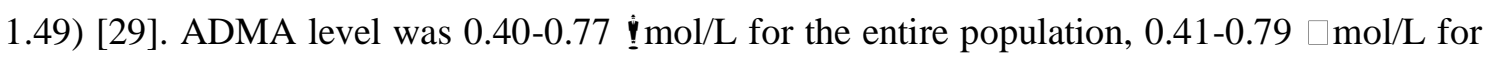
men, $0.38-0.73 \square \mathrm{mol} / \mathrm{L}$ for women under 45 years old, and $0.41-0.84 \square \mathrm{mol} / \mathrm{L}$ for women above 45 years old [29]. Past studies showed that plasma ADMA levels were higher in obesity [30]. In

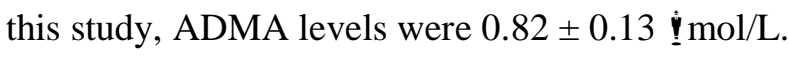

Based on several previous studies, plasma ADMA levels were associated with the risk of AMI and cardiovascular death [7], unchanged with weight loss in obesity [31], hypertension and insulin resistance [32], resistance insulin at the beginning of diabetes [33], HOMA-IR in prehypertension [34], BMI in overweight [35], and HOMA-IR in obesity [36]. In this study, ADMA had a significant correlation with FPG, HbA1c, and TG parameters $[r=-0.506, p=$ $0.001 ; \mathrm{r}=-0.334, \mathrm{p}=0.013$, and $\mathrm{r}=-0.315 . \mathrm{p}=0.017$, respectively] in obesity.

\section{Conclusion}

The association between ADMA and increased cardiovascular risks was related to glucose metabolism, lipid, and insulin resistance with various unknown mechanisms. Thus, further and extensive research should be done to determine the role of ADMA in the risk of cardiovascular disease.

\section{Acknowledgments}

The authors gratefully acknowledge that the present research is supported by Ministry of Research and Technology and the Higher Education Republic of Indonesia, Research and Community Service, Universitas Sumatera Utara.

\section{Conflict of Interests}

The authors declare that there is no conflict of interests regarding the publication of this paper. 


\section{REFERENCES}

[1] Zoccali C, Bode-Boger S, Mallamaci F, Benedetto F, Tripepi G, Malatino L, et al. Plasma Concentration Of Asymmetrical Dimethylarginine And Mortality In Patients With EndStage Renal Disease: A Prospective Study. Lancet. 2001;358:2113-7.

[2] Tsikas D, Rode I, Becker T, Nashan B, Klempnauer J, Frolich JC. Elevated plasma and urine levels of ADMA and 15(S)-8-iso-PGF2alpha in end-stage liver disease. Hepatology. 2003;38:1063-4.

[3] Kielstein JT, Bode-Boger SM, Klein G, Graf S, Haller H, Fliser D. Endogenous Nitric Oxide Synthase Inhibitors And Renal Perfusion In Patients With Heart Failure. Eur J Clin Invest. 2003;33: 370-5.

[4] Lin KY, Ito A, Asagami T, Tsao PS, Adimoolam S, Kimoto M, et al. Impaired Nitric Oxide Synthase Pathway In Diabetes Mellitus: Role of Asymmetric Dimethylarginineand Dimethylarginine Dimethylaminohydrolase. Circulation. 2002;106:987-92.

[5] Savvidou MD, Hingorani AD, Tsikas D, Frolich JC, Vallance P, Nicolaides KH. Endothelial Dysfunction And Raised Plasma Concentrations Of Asymmetric Dimethylarginine In Pregnant Women Who Subsequently Develop Pre-Eclampsia. Lancet. 2003;36:1511-7.

[6] Boger RH, Bode-Boger SM, Thiele W, Junker W, Alexander K, Frolich JC. Biochemical Evidence For Impaired Nitric Oxide Synthesis In Patients With Peripheral Arterial Occlusive Disease. Circulation. 1997;95:2068-74.

[7] Borgeraas H, Hertel JK, Svingen GVT, Pedersen ER, Seifert R, Nygård O, et al. Association between Body Mass Index, Asymmetric Dimethylarginine and Risk of Cardiovascular Events and Mortality in Norwegian Patients with Suspected Stable Angina Pectoris. PLoS ONE. 11(3):1-13.

[8] Goodson NJ, Symmons DP, Scott DG, Bunn D, Lunt M, Silman AJ. Baseline levels of Creactive Protein And Prediction Of Death From Cardiovascular Disease In Patients With Inflammatory Polyarthritis: a ten-year follow up study of a primary care based inception cohort. Arthritis Rheum. 2005;52:2293-99.

[9] Lobo SM, Lobo FR, Bota DP, Lopes-Ferreira F, Soliman HM, Mélot C et al. C-reactive Protein Levels Correlate With Mortality And Organ Failure In Critically Ill Patients. Chest .2003;123:2043-9.

[10]Man P, Connett JE, Anthonisen NR, Wise RA, Tashkin DP, Sin DD. C-reactive protein and mortality in mild to moderate chronic obstructive pulmonary disease. Thorax. 2006;61(10):849-53.

[11]Blake GJ, Ridker PM. Inflammatory Bio-Markers And Cardiovascular Risk Prediction. J Intern Med. 2002;252:283-94.

[12]Baylis C. Arginine, arginine analogs and nitric oxide production in chronic kidney disease. Nat Clin Pract Nephrol. 2006;4:209-20.

[13]Clinical Guidelines on the Identification, Evaluation, and Treatment of Overweight and Obesity in Adults. The Evidence Report. National Institutes of Health. Obes Res 1998;6(2):51S-209S.

[14]Colak A, Coker I, Diniz G, Karademirci İ, Hanci T \& Bozkurt U. Interleukin 6 and tumor necrosis factor-alpha levels in women with and without glucose metabolism disorders. Turkish Journal of Biochemistry. 2010;3(35):190-4.

[15]El Assar M, Angulo J, Santos-Ruiz M, Adana RD, Pindado JC, Sánchez-Ferrer ML, et al. Asymmetric dimethylarginine (ADMA) Elevation And Arginase Up-Regulation Contribute To Endothelial Dysfunction Related To Insulin Resistance In Rats And Morbidly Obese Humans. Journal of Physiology. 2016;594(11):3045-60.

[16]Peraldi P, Hotamisligil GS, Buurman WA, White MF \& Spiegelman BM. Tumor necrosis factor (TNF)-alpha inhibits insulin signaling through stimulation of the p55 TNF receptor and activation of sphingomyelinase. Journal of Biological Chemistry. 1996;271(22):13018-22.

[17]Eliana F, Suwondo P, Makmun LH, Harbuwono DS. ADMA as a Marker of Endothelial Dysfunction in Prediabetic Women. Acta Med Indones-Indones $\mathrm{J}$ Intern Med. 
2011;43(2):92-8.

[18]Huang S, Xu Y, Peng WF, Cheng J, Li HH, Shen LS, Xia LL. A Correlational Study Between Serum Asymmetric Dimethylarginine Level And Impaired Glucose Tolerance Patients Associated With Obesity. J Cell Physiol. 2018:1-6.

[19]WHO. Obesity: Preventing and managing the global epidemic. Report of a WHO Consultation. WHO Technical Report Series 894. Geneva: WHO,2000.

[20]Kelm M. Flow-mediated dilatation in human circulation: Diagnostic and Therapeutic aspects. Am J Physiol Heart Circ Physiol. 2002;282:1-5.

[21]Standards of Medical Care in Diabetes 2010. American Diabetes Association. Diabetes Care. 2010;33:S11-61.

[22] Miyazaki H, Matsuoka H, Cooke JP, Usui M, Ueda S, Okuda S, et al. Endogenous Nitric Oxide Synthase Inhibitor: A Novel Marker Of Atherosclerosis. Circulation 1999;99:1141-6.

[23] Matthews DR, Hosker JP, Rudenski AS, Naylor BA, Treacher DF, et al. Homeostasis model assessment: insulin resistance and $\beta$-cell function from fasting plasma glucose and insulin concentrations in man. Diabetologia. 1985;28:412-9.

[24]Landim MBP, Casella Filho A, Chagas ACP. Asymmetric dimethylarginine (ADMA) and Endothelial Dysfunction: Implications for Atherogenesis. Clinics 2009;64(5):471-8.

[25]Vita JA, Keaney Jr JF. Endothelial function: a barometer for cardiovascular risk? Circulation. 2002;106:640-2.

[26]Rubanyi GM. The role of endothelium in cardiovascular homeostasis and diseases. J Cardiovasc Pharmacol. 1993;22(4):S1-S4.

[27]Böger RH1, Bode-Böger SM, Szuba A, Tsao PS, Chan JR, Tangphao O, et al. Asymmetric dimethylarginine (ADMA): a novel risk factor for endothelial dysfunction: its role in hypercholesterolemia. Circulation. 1998;98(18):1842-7.

[28]Fard A1, Tuck CH, Donis JA, Sciacca R, Di Tullio MR, Wu HD, et al. Acute elevations of plasma asymmetric dimethylarginine and impaired endothelial function in response to a high-fat meal in patients with type 2 diabetes. Arterioscler Thromb Vasc Biol. 2000 Sep;20(9):2039-44.

[29]Hov G, Sagen E, A. Bigonah \& Sberg AA. Health-associated reference values for arginine, asymmetric dimethylarginine (ADMA) and symmetric dimethylarginine (SDMA) measured with high-performance liquid chromatography G. Scand J Clin Lab Invest. 2007;67:868-76.

[30]McLaughlin T, Stuhlinger M, Lamendola C, Abbasi F, Bialek J, Reaven GM, et al. Plasma asymmetric dimethylarginine concentrations are elevated in obese insulin-resistant women and fall with weight loss. J Clin Endocrinol Metab. 2006;91:1896-900.

[31]Rudofsky G, Roeder E, Merle T, Hildebrand M, Nawroth PP, Wolfrum C. Weight Loss Improves Endothelial Function Independently of ADMA Reduction in Severe Obesity. Horm Metab Res. 2011;43:343-8.

[32]Perticone F, Sciacqua A, Maio R, Perticone M, Galiano Leone G, Bruni R, et al. Endothelial dysfunction, ADMA and insulin resistance in essential hypertension. Int $\mathrm{J}$ Cardiol. 2010;142(3):236-41.

[33]Nakhjavani M, Karimi-Jafari H, Esteghamati A, Khalilzadeh O, Asgarani F, Ghadiri-Anari A. ADMA is a correlate of insulin resistance in early-stage diabetes independent of hsCRP and body adiposity. Annales d'Endocrinologie. 2010;71:303-308.

[34]Novianti ME, Bakri S, Arief M, Sandra F. Correlation between HOMA-IR with ADMA in Prehypertension. Indones Biomed J. 2013;5(3):169-72.

[35]Eid HMA, Arnesen H, Hjerkinn EM, Lyberg T, Seljeflot I. Relationship Between Obesity, Smoking, and the Endogenous Nitric Oxide Synthase Inhibitor, Asymmetric Dimethylarginine Metabolism. 2004;53(12):1574-9.

[36] Hidayat A, Wijaya A, Alrasyid H. Correlation between IL-6, hsCRP, ET-1, ADMA and HOMA-IR in Central Obese Men. Indones Biomed J. 2011;3(1):43-50. 